\title{
ESTADO - ENTIDADE DE PREVIDÊNCIA DE SERVIDORES PÚBLICOS - IMUNIDADE TRIBUTÁRIA
}

\section{PARECER}

\section{I - CONSULTA}

1. Na linha da moderna seguridade social dos servidores públicos (Constituição Federal, arts. 40; 149, parágrafo único e 249), o Estado do Paraná, através da Lei PR $\mathrm{n}^{\mathrm{Q}}$ 12.398, de 30.12.98, e por transformação da autarquia Instituto de Previdência e Assistência aos Servidores do Estado - IPE, criou a PARANAPREVIDÊNCIA, entidade através da qual o Govemo paranaense cumpre suas obrigações de seguridade funcional, e administra o respectivo Sistema, compreendendo os Programas de Previdência e de Serviços Médico-Hospitalares, de que são beneficiários os agentes públicos estaduais, seus dependentes e pensionistas.

2. Consulta-nos a Diretoria Jurídica da instituição se é essa beneficiária da imunidade tributária, contemplada no art. 150, VI, $a$ e $c$, da Carta Magna Nacional.

\section{II - A IMUNIDADE TRIBUTÁRIA DO ARTIGO 150, VI, A E C, DA CF}

1. A PARANAPREVIDÊNCIA identificase, nos termos dos arts. $2^{\circ}$ e $3^{\circ}$ da Lei PR $n^{\circ}$ 12.398, de 30.12.98, como:

a) instituição não-lucrativa;

b) serviço social autônomo;

c) entidade paradministrativa de direito privado; d) ente de cooperação governamental, instrumento de cumprimento, pelo Estado do $\mathrm{Pa}$ raná, para com seus servidores, e respectivos dependentes, de suas obrigações previdenciárias e de assistência à saúde.

2. Pode dizer se, portanto, que correta é a disposição do art. 100 do citado diploma normativo, segundo a qual

“a PARANAPREVIDÊNCIA goza, nos termos do prescrito pelo art. 150, VI, alíneas $a$ e $c$, da Constituição Federal, de imunidade em relação aos impostos federais e municipais;

sendo, ademais,

"beneficiária de isenção dos tributos estaduais."

3. Com efeito, a PARANAPREVIDÊNCIA é, subjetiva e objetivamente, um serviço estadual, e, portanto, sua situação jurídica se subsume na previsão da alínea a do art. 150, VI, da $C F$.

4. Organicamente, como ente paradministrativo integra o setor público estadual, fazendo parte de sua organização, vinculada que está à Secretaria Especial de Assuntos de Previdência, tendo sido, nos termos do disposto no art. $37, \S 8^{\circ}$, da Carta Magna Nacional, com o texto da Emenda Constitucional $\mathrm{n}^{\mathrm{q}}$ 19.98, celebrado contrato de gestão, instrumentalizador da supervisão governamental sobre a entidade.

5. Funcionalmente, caracterize-se como serviço público estadual, porque é o gestor do 
regime de previdência estabelecido pelo art. 40 da Constituição Federal.

$\mathrm{O}$ art. $3^{\circ}$ da Lei PR $n^{2} 12.398 / 98$ é explícito na identificação da entidade como elemento de "cumprimento, pelo Estado do Paraná, de suas obrigações de Seguridade Funcional", sendo ela o ente gestor do "respectivo Sistema, segundo regime de benefícios e serviços previsto" na Lei.

5.1. Assinale-se que a PARANAPREVIDÊNCIA não é uma entidade de previdência privada, e, portanto, diversamente, não é integrante do setor privado, no qual os entes daquela espécie atuam como colaboradoras do Poder Público, em caráter complementar ao regime geral de previdência social, sendo, o regime de previdência privada, de índole facultativa, e autônomo em relação ao público.

O que é personalizado pela PARANAPREVIDÊNCIA é o próprio regime público de previdência dos agentes do Estado - e não, um regime complementar - tendo por futuro o estatuído pelo art. 40 da CF: trata-se, como explícita o art. $1^{\mathfrak{Q}}$ da Lei PR $\mathrm{n}^{\mathbb{Q}} 12.398 / 98$, do Sistema de Seguridade Funcional do Estado do Paraná, compreendendo os Programas de Previdência e os Serviços Médico-Hospitalares, de que são beneficiários os agentes públicos estaduais e seus dependentes e os pensionistas.

5.2. A PARANAPREVIDÊNCIA é ente descentralizado, mas governamental, componente do setor público. É ente de cooperação, e, portanto, integrante da Paradministração, do Poder Administrativo lato sensu.

5.3. Criada por lei, vinculada a uma Secretaria de Estado, é destinatária de contribuições sociais (art. 149, parágrafo único, da CF), espécie do gênero prestações pecuniárias públicas, que o SUPREMO TRIBUNAL FEDERAL tem entendido "que se revestem de indiscutível caráter tributário" (RTJ 143: $313 \mathrm{e}$ 684; 149; 654; DJU, de 18.11.99, p. 51.152).

5.4. A PARANAPREVIDÊNCIA não é, apenas, um serviço social autônomo, mas um ente dessa índole que integra o Poder Administrativo Estadual.

5.5. É tipicamente de cooperação, porque para a sua gestão e formação patrimonial con- tribuem o Poder Público, com recursos de seu orçamento de seguridade social; e os agentes públicos, com suas contribuições de natureza pública.

5.6. A posição da PARANAPREVIDÊNCIA é semelhante à das universidades e instituições de ensino superior fundacionais: de direito privado, dotadas da necessária autonomia, mas integrantes do Governo. São governamentais, públicas, oficiais.

6. Há-de acentuar-se que a PARANAPREVIDÊNCIA resultou da transformação, pelo art. $2^{\mathrm{O}}$ da Lei PR $\mathrm{n}^{\mathrm{Q}} 12.398 / 98$, de uma autarquia, o IPE, transformação essa que consistiu na passagem da condição de pessoa jurídica de direito público a pessoa jurídica de direito privado, mas sua teleologia previdenciária e assistencial se manteve.

É consabido que a natureza pública ou privada não interfere, tanto que o $\S 2^{\circ}$ do art. 150 do Texto Magno Nacional estende a chamada imunidade recíproca, que protege a administração direta, as autarquias (públicas), às fundações instituídas e mantidas pelo Poder Público (privadas).

6.1. E, em ambos os casos, a vedação impositiva preserva o patrimônio, a renda e os serviços desses entes.

"vinculados a suas finalidades essenciais ou às delas decorrentes."

6.2 Assim, quando se trata de fundação, de instituição governamental, estão albergados, na imunidade impositiva, não só o patrimônio, a renda e os serviços vinculados a suas finalidades essenciais, como as finalidades dessas decorrentes.

Estão, pois, abrangidas, por exemplo, as aplicações financeiras, os investimentos, que, mais do que necessários, são obrigatórios, e, portanto, decorrentes de suas finalidades essenciais, para que, atendendo ao princípio do equilíbrio financeiro e atuarial, haja a adequada constituição de reservas garantidoras dos benefícios assegurados.

7. Há ressalva, no $\S 3^{2}$ do mesmo art. 150 da CF, quanto à não-incidência da regra, quando se trate de serviço

"em que haja contraprestação ou pagamento de preços ou tarifas pelo usuário".

Mas essa cláusula limitativa nada tem a ver 
com a hipótese, porque o regime previdenciário público é, por força da própria $\mathrm{CF}$ (art. 40), de natureza contributiva, mas contribuição social não é preço, nem tarifa, como já observado, tendo base no art. 149, parágrafo único, da Constituição; nem, tampouco, servidor público, participante, de plano de benefícios, é usuário.

8. Outrossim, a PARANAPREVIDÊNCIA é, inquestionavelmente, uma instituição, e, assim, uma espécie de fundação governamental.

8.1. Efetivamente, está assim caracterizada, de maneira expressa, no art. $2^{9}$ da Lei PR $n^{0}$ $12.398 / 98$.

8.2. Quer sociológica, quer juridicamente, a instituição, em sentido lato, envolve a noção de organização cuja função social é a satisfação de necessidades coletivas; e detentora de um poder de império suficiente para dar eficácia à sua atividade, de modo a realizar essa função.

8.3. Em significado jurídico estrito, a instituição é uma das espécies de fundação, exatamente aquela em que o substrato personificado é, substancialmente, a organização, a estrutura orgânica.

8.3.1. Este tipo de fundação coloca-se ao lado da fundação patrimônio, que é a única forma fundacional que pode ser criada pelos particulares, nos termos do disposto nos arts. 24 e seguintes do Código Civil, e cujo núcleo do suporte personalizado é u'a massa de bens, um acervo patrimonial.

8.3.2. A distinção é mais uma questão de tônica: em ambas, fundação-instituição e fundação-patrimônio, a personalidade jurídica abrange o estabelecimento e o patrimônio.

Assim, o Código Civil e o Código de Processo Civil, se destacam o segundo, exigem que se estabeleça a forma de sua administração (CC, art. 24; CPC, arts. 1.199 e 1.202). E o CPC tem, como designação do Capítulo em que trata da matéria fundacional, "Da Organização e da Fiscalização das Fundações".

Por seu turno, a PARANAPREVIDÊNCIA, como exemplo de instituição, tem sua estrutura personificada, mas lhe é inerente a titularidade de Fundos (de Previdência, Financeiro e de Serviços Médico-Hospitalares), além do Patrimônio Geral. E fundo personificado é fundação.

8.3.3. Os Poderes Públicos podem instituir fundações-patrimônio, mas, quando se trata de entes fundacionais que vão compor o setor governamental, seja na administração indireta stricto sensu, seja na paradministração, na administração de cooperação, a formatação é a da fundação-instituição, que somente o Governo pode criar.

É ela a espécie que se encontra definida no art. $1^{\varrho}$ da Lei federal $n^{Q} 7.596$, de 10.04.87, que alterou o art. 50, IV, do Decreto-lei $\mathrm{n}^{\mathrm{Q}}$ 200, de 25.02.67.

8.3.4. A autarquia é uma fundação-instituição, só tem que de direito público; enquanto a sua co-irmã é a fundação-instituição de direito privado.

Podemos dizer, portanto, que a autarquia é a instituição de direito público, enquanto a instituição 'stricto sensu', tal como considerada pela Lei $P R n^{2} 12.938 / 98$, é a autarquia de direito privado.

8.3.5. Daí, a ausência de qualquer obstáculo ou dificuldade na transformação da autarquia IPE na instituição PARANAPREVIDÊNCIA.

8.3.6. Não se poderá jamais falar de privatização, neste processo de transformação.

Privatização é passar a organização, a atividade para o setor privado, sendo, por isso, uma forma de desestatização.

No caso da PARANAPREVIDÊNCIA, houve a transformação do IPE em pessoa jurídica de direito privado, mas sem alheamento do setor público, que, como é curial, abriga entes públicos (administração direta e autárquica) e privados (empresas públicas e mistas e fundações públicas e paradministrativas).

A PARANAPREVIDÊNCIA não é administrada: é criatura do Governo, sob sua supervisão, e, como integrante do setor público, é realizadora de atividade estatal.

8.4. Nesta linha, a PARANAPREVIDÊNCIA é destinatária das regras do art. 150, VI, a, e $\S 2^{2}$, da CF.

9. O art. 100 da Lei PR n ${ }^{9} 12.398 / 98$ proclama, ainda, que a PARANAPREVIDÊNCIA goza, também, da imunidade assegurada pela alínea c do inciso VI do art. 150, da CF, por ser instituição de assistência social. 
9.1. Estatui o art. 150, VI, c, da Constituição Federal de 1988 que, dentre as limitações do poder de tributar, se insere a vedação, à União, aos Estados, ao Distrito Federal e aos Municípios, de instituir impostos sobre o patrimônio, renda ou serviços das

"instituições de educação e de assistência social, sem fins lucrativos, atendidos os requisitos da lei."

9.2. A vedação é instituto de Direito Constitucional, não se confundindo com a proibição.

Esta última é tradução do dever de abstenção, enquanto a primeira consiste na inexistência de um poder jurígeno em relação a determinado objeto.

Daí ser correta a caracterização da vedação como limite ao poder de tributar, ou seja, um corte no respectivo conteúdo, uma não-inclusão no mesmo; e não apenas, limitação ao respectivo exercício.

Por isso, o art. 150 da CF identifica esse limite como uma das garantias constitucionalmente asseguradas ao contribuinte: garantia, sob a modalidade, exatamente, de vedação ao legislador, que, pelo princípio da reserva legal é quem institui impostos; garantia, portanto, de intangibilidade do objeto subtraído ao âmbito do poder impositivo.

Vedação, repetimos, dirigida ao legislador, eis que se refere à impossibilidade jurídica de instituir imposto; e não, apenas, de exigir (art. 150, I) ou de cobrar (inciso III).

Como ensina PONTES DE MIRANDA (Comentários à Constituição de 1967, São Paulo, RT, 1967, II: 392), “a regra jurídica de imunidade é regra jurídica no plano das regras jurídicas de competência dos poderes públicos - obsta à atividade legislativa impositiva, retira ao corpo, que cria impostos, qualquer competência para o pôr, na espécie."

9.3. A imunidade impositiva em tela deixa de fora do conteúdo do poder governamental de tributar o "patrimônio, renda ou serviços"; que sejam "relacionados com as finalidades essenciais" (art. 150, $\S 4^{\circ}$ ) das "instituições de educação e de assistência social, sem fins lucrativos" e isto, "atendidos os requisitos da lei".

9.4. Trata-se de imunidade dita subjetiva, pois que leva em conta a qualidade daquele que seria o sujeito passivo da obrigação tributária, não fora a vedação.

Repita-se a lição de PONTES ( $i b$ ), segundo a qual, na imunidade, "há qualidade de pessoa, ou do bem, que se erige versus Estado".

9.5. Reportemo-nos ao que já analisamos, em termos do conceito de instituição, em suas várias acepções. $\mathrm{E}$ aduzamos que a $\mathrm{CF}$ de 1988 empregou o termo instituição no sentido de entidade.

9.5.1. Com efeito, a CF emprega o vocábulo em foco em trinta e um dispositivos relativos a diferentes matérias, evidenciando que o uso do substantivo em tela se deu, também no caso específico da regra relativa à imunidade, com aquele significado. Não se podem conciliar características outras que alguns pretendem embutir no conceito de instituição, com, por exemplo, a categoria das instituições financeiras, a que alude o art. 192 da Constituição.

9.5.2. Tanto o sentido do termo instituição corresponde ao de entidade em geral, que JOSÉ CRETELLA JÚNIOR, dentre outros ilustres publicistas, ao analisar o dispositivo constitucional em pauta, observa que "a Constituição de 1946, art. 31, V, também declarava imunes essas entidades" (Comentários à Constituição, Forense, Rio, 1992, VII: 3.560).

Pode citar se, ainda, IVES GANDRA MARTINS, que, cuidando desta imunidade, alude a "entidades de assistência social" (Comentários à Constituição, Saraiva, São Paulo, 1990, vol. 06, Tomo I, p. 183).

9.5.3. Mas não se precisa sair do texto constitucional, e nem mesmo do âmbito do art. 150, para chegar se a esta conclusão: o $\$ 4^{\circ}$ deste, quando se reporta à vedação da alínea c do inciso VI do art. 150, emprega a cláusula "finalidades essenciais das entidades" nela mencionadas.

10. No campo específico da História e da Teoria das Pessoas Jurídicas, os vocábulos instituto e seu cognato, instituição, sempre estiveram ligados à figura da fundação.

10.1. Sempre com um sentido social, a instituição deita suas raízes remotas na Grécia, no século $\mathrm{V}$ a.C., destinando-se ao culto dos deuses; e, em Roma, nos últimos anos da República e nos primeiros do Principado, ob- 
jetivando a distribuição de alimentos, a manutenção de crianças pobres. $\mathrm{O}$ instituto, a fundação, como espécie de pessoa jurídica distinta das corporações (sociedades, associações) os collegia, as societates, os sodalitia -, veio, porém, efetivamente a desenvolverse no período pós-clássico, em parte sob a influência helênica, e, em outra parte, já na fase do Império Cristão, da religião e da caridade, como nos ensina MATOS PEIXOTO (Curso de Direito Romano, Rio, Haddad, $4^{a}$ ed., 1960, p. 353): "Eram as igrejas, os mosteiros, os hospícios, os hospitais e os estabelecimentos de beneficência ('pia corpora'; 'piae causae'; 'venerabiles domus'), muito numerosos nessa época e designados por termos helênicos: para os indigentes ("ptochotrophia', para os órfãos ('orphantrophia', para as crianças pobres em geral ('brephotrophia', para os enfermos ('nosocomia'), para os velhos desvalidos ('gerontocomia'), para os estrangeiros necessitados ('xenodochia')".

10.2. Já, à época, elemento identificador necessário à existência da pessoa jurídica da espécie era o destaque do patrimônio a um determinado fim, caracterizando-se sua criação como uma "liberalidade modal" (cf. VANDICK LONDRES DA NÓBREGA, História e Sistema do Direito Privado Romano, Rio, Freitas Bastos, 1955, p. 127), e consubstanciando-se o substrato jurígeno personalizado em um estabelecimento autônomo, tudo sob a gestão de administradores específicos. Interessante observar que já havia uma inspeção exterior, realizada pelos Bispos, a fim de se aferir o atendimento à consecução das finalidades institucionais.

Com o Direito Canônico, consolidou-se, neste sentido, o conceito de instituto, de instituição, próprio desta espécie de pessoa jurídica, isto é, o estabelecimento criado e estruturado, exteriormente, por vontade alheia, visando à consecução de um fim, mercê da gestão de um patrimônio.

FRANCESCO RUFFINI, da Universidade de Gênova, no estudo intitulado La Classificazione delle Persone Giuridiche in Sinibaldo dei Fieschi (Innocenzo IV) ed in Federico Carlo di Savigny ('in' Studi Giuridichi in Onore di F. Schupfer, Bocca, 1891, Parte Se- gunda, p. 321), tratando do Direito Medieval, assinala que a instituição é posterior à corporação, sendo aquela sinônima de fundação.

Salienta que o Direito Romano Cristão já contrapunha à corporação o que chamava de 'pius locus' ou de 'pia causa', noção que o Direito Canônico desenvolveu imensamente, e que uma doutrina mais aperfeiçoada veio a qualificar como instituições ou fundações.

Expõe a teoria de GIERKE, no que diz respeito à distinção entre "corporação" $\mathrm{e}$ "instituição": "Conforme invero alla sua teoria, che nell'esistenza di una volontà unitaria vede il substrato della personalità, il GIERKE definisce la corporazione come l'unità, il cui corpo è formato da un organismo corporatizio, e la cui volontà è podotta dal di dentro, cioè dalla volontà dei più che si unisce. II principio vivificatore della corporazione è pertanto una volontà immanente nella persona collettiva. L'istituzione invece è una unità imposta dal di fuori a una determinata colleítivià, il suo corpo è costituito da un organismo istituzionale, la sua volontà è formata dal distacco e dalla individualizzazione di una porzione di una volontà diversa e superiore alla collettività. II principio vivificatore dell'istituzione è pertanto una volontà non immanente nella collettività, ma trescendente."

11. Ora, este perfil é, exatamente, o da fundação, no Direito Brasileiro.

11.1. Podemos dizer que a fundação-patrimônio e a fundação-instituição, nos termos em que está colocado seu regime no Direito Brasileiro, como espécies do gênero das pessoas jurídicas, têm atributos que as tornam o instrumento ideal para o atendimento de fins sociais; e são, por si mesmas, instituições neste sentido sócio-jurídico finalístico.

11.2. Elas não têm membros, ou seja, nem sócios, nem associados, eis que a membridade é requisito necessário e próprio das corporações (sociedades e associações), que, em consequiência, ostentam, como órgão máximo e indispensável de sua estrutura, a assembléia geral, onde atuam os membros da entidade, e que podem alterá-la - inclusive quanto ao objeto social - e, até mesmo, extingui-la: é órgão dominante, que expressa a vontade ima- 
nente, interna, superior, que comanda o destino corporativo.

Contam, tão-somente, com órgãos de administração, integrados por gestores da organização, administradores do patrimônio institucionais, órgãos esses servientes, pois sua atuação está comprometida, funcionalmente, com o fim institucional, que não podem modificar, que é imutável, e que já encontram preestabelecido no ato de instituição da entidade, cuja existência não podem eliminar ad libitum.

11.3. Com efeito, fim e duração da instituição são elementos que cabem ao instituidor - aquele que pratica o ato deflagrador do procedimento de criação do ente - estabelecer.

Quanto ao aspecto finalístico, é relevante gizar que, no Direito Brasileiro, tem ele de ser social, de índole social.

A extinção da instituição, salvo as hipóteses de existência a termo final ou sob condição resolutiva, inclusive por visar à realização de fim em si mesmo de cometimento temporário, só pode dar-se pela superveniência de inviabilidade, por causas fáticas ou jurídicas reconhecidas por quem de direito.

11.4. Finalmente, um dado básico das virtudes institucionais: exatamente em razão de sua estrutura impessoal; da perenidade existencial; de sua teleologia social, a fundação tem de estar sob o velamento, a provedoria de terceiro, que fiscalize a administração da entidade, com vistas à permanente aferição da legitimidade de sua investidura e de sua atuação; da consonância desta com os fins; verificando - e prestando o auxílio correspondente, quando necessário - se se está desenvolvendo a melhor gestão do patrimônio, de modo a se obterem mais recursos, e, com menos ônus, lograr-se a consecução mais completa possível dos mencionados fins.

Sendo entidade particular, o velamento cabe ao Ministério Público (Código Civil, art. 26); se governamental, um ente público (um Ministério, uma Secretaria de Estado) exerce a provedoria.

11.5. Sendo a vida social - e, assim, a vida jurídica eminentemente relacional, é claro que a criação da instituição; a dotação do patri- mônio; sua estruturação orgânica, a respectiva titularização e o funcionamento pelos administradores, bem como a fixação dos fins sociais a serem alcançados, todo esse conjunto tem de ter como objetivo último o benefício de seres humanos, que são os destinatários da instituição, e que podem constituir um conjunto com maior ou menor número de elementos, toda uma comunidade, um segmento, uma classe dessa.

Desde logo, cumpre assinalar que, embora possa ser maior ou menor o conjunto - aberto ou fechado - desses beneficiários, sua qualificação será sempre social, comunitária.

11.6. A apresentação desse panorama geral das peculiaridades institucionais torna clara sua pertinência como instrumento de realização de fins sociais, quando se deseja utilizar um meio impessoal, objetivo, duradouro, confiável, inclusive pela sujeição à fiscalização externa.

12. Pode, pois, concluir-se que, no Direito Brasileiro, toda fundação, patrimônio ou organização, é uma instituição, como organização ou função social.

É certo que o termo instituição foi, progressivamente, tomando acepção mais larga, a abranger, desde que atendida a teleologia social, associações e sociedades.

Mas isto não infirma a conclusão: se, nem toda instituição é fundação, toda fundação é instituição.

13. O art. 150, VI, c, da CF, dirige-se a instituições de assistência social.

13.1. Assistência social é expressão que admite um sentido lato e um sentido estrito.

SACHA CALMON (Comentários à Constituição de 1988, 2a ed., p. 367/368) mostra que, se, em termos de seguridade social, no Título VIII, Capítulo II, da CF, a assistência social é, stricto sensu, um dos segmentos daquela (art. 203), ao lado da previdência social (art. 201), já no sentido tradicional, amplo, a assistência social é o gênero:

“THEMISTOCLES CAVALCANTI chega a ser enfático: 'Um dos pontos fundamentais da assistência social é a organização de instituição de seguro e previdência social' ('Tratado de Direito Administrativo; vol. I, p. 253). 
Aí a previdência é espécie do gênero assis. tência social."

E aduz:

"FRITZ FLEINER leciona: 'El Seguro Social obrero es un acto de Asistencia Social del Estado a favor de los ciudadanos' ('Instituciones de Derecho Administrativo'; Barcelona. 1933, p. 261). USINGER, no capítulo sob o título de 'El Fin de Asistencia Social'; predica: '... También encara la previsión social, la tutela del debil, la protección del anciano y al invalido' ('Fines Del Estado'; Rosário, 1958, p. 381/382). Mas é GUILHERMO CABANELLAS, no seu 'Diccionario de Derecho Usual' (B. Aires, 1953), ao tratar do verbete "assistência social"; que demonstra ser a previdência um dos componentes da assistência social: '... Además de la ya señalada clasificación de la 'asistencia social' en 'publico, privado y mixta; se divide también esta institución por su finalidad, en 'preventiva' y'curativa'. Al primer grupo corresponden los seguros sociales, la organización de la pequeña propiedad, el ahorro... En cambio, son "curativas' las indemnizaciones por desocupación, por acidentes de trabajo, invalidez ou vejez y por muerte del cabeza de família, a los dependian economicamente de el...' Vale dizer, para Cabanellas, respeitado entre juslaboristas e jusprevidenciaristas, a 'previdência faz parte da assistência social, não se the contrapõe (assistência social preventiva)'."

13.2. Pode dizer-se que, assim como as origens da assistência social preventiva, da previdência social, radicam-se na poupança individual ou familiar (autoproteção), nos seguros privados e no mutualismo (heteroproteção), as da assistência social curativa estão na caridade, na benemerência, na filantropia, que continuaram a existir, mas a que se somaram outras espécies de ações assistenciais privadas e públicas.

13.3. A Assistência Social tem âmbito amplo, não se confinando à Assistência Oficial, Pública, não contributiva, nem em termos de agente, nem de objeto.

A própria CF de 1988 alude a várias formas de assistência. Citemos, dentre outras: (1) art. 50, LXIII: "assistência da família e de advogado ao preso"; (2) art. 5, LXXIV: “assistên- cia jurídica integral e gratuita'; (3) art. $6^{\circ}$, caput "assistência aos desamparados"; (4) art. 60, XXV: "assistência gratuita aos filhos e dependentes dos trabalhadores urbanos e rurais, desde o nascimento até seis anos de idade em creches e pré-escolas"; (5) art. 23 , II: "saúde e assistência pública"; (6) art. 24, XIII: "assistência jurídica”; (7) art. 150, VI, c: "instituições de assistência social"; (8) arts. 194; 195, $\$ \S 2^{\circ}$ e 70; 203 e 204 : "assistência social como integrante da seguridade social"; (9) art. 208, VII: "assistência à saúde do educando"; (10) art. $211, \S 1$ 10. "assistência federal, técnica e financeira, dos Estados, Municípios e DF, em matéria de ensino"; (11) art. 226, § 80: "assistência, do Estado, à família"; (12) art. 227, § 10: "assistência integral, pelo Estado, à saúde da criança e do adolescente"; (13) art. 227, § 3, VI: "estímulo do Poder Público, através de assistência jurídica ao acolhimento, sob a forma de guar$\mathrm{da}$, de criança ou adolescente órfăo ou abandonado"; (14) art. 227, § 50: "assistência, pelo Poder Público, das adoções"; (15) art. 245: "assistência, pelo Poder Público, aos herdeiros e dependentes carentes de pessoas vitimadas por crime doloso"; (16) ADCT, art. 53: "assistência médica, hospitalar e educacional gratuita aos ex-combatentes, extensiva aos dependentes".

13.4. A assistência é atividade típica do Direito Social, ramificação jurídica básica, que se coloca ao lado do Direito Público e Privado, e que parte do pressuposto de que as pessoas, os grupos, as classes, os diversos segmentos da sociedade são desiguais - por natureza, por sorte, por diferentes outros fatores - e, por isso, há que buscar, senão a equalização, a erradicação das desigualdades sociais e regionais, pelo menos a redução, com a satisfação de carências, de hipossuficiências.

13.5. Toda assistência é, portanto, neste quadro, social, é de Direito Social; e assume as mais variadas formas, podendo ser prestada pelos Poderes Públicos ou pelos particulares, os primeiros no cumprimento de suas finalidades próprias; os últimos sob modalidade das mais nobres da livre iniciativa, eleita, pela CF, como valor social (art. $1^{\circ}$, IV), e inserin- 
do-se, com perfeição, no conjunto dos demais fundamentos e objetivos básicos do Estado Democrático de Direito: a cidadania, a dignidade da pessoa humana, a construção de uma sociedade livre, justa e solidária, sem discriminaçōes, e visando à realização do desenvolvimento nacional (CF, arts. $1^{\circ}$, II e III; e $3^{\circ}$, I, II e IV).

13.6. Trata-se da satisfação das necessidades sociais, sejam coletivas, comunitárias, até mesmo difusas: sejam as necessidades de cada indivíduo, enquanto integrante de um grupo social; e deste, como coletividade.

Quando atendidas pelo Governo, a atuação estará regida pelo Direito Público e pelo Direito Social; e o organismo exercente da atividade é a autarquia, é uma organização social autônoma paradministrativa, uma fundação, uma instituição.

Se desenvolvida a atuação pelo particular, estará ela submetida ao Direito Privado e Social, sendo veiculada por entidade de Direito Privado (associação, sociedade, fundação).

13.7. Na satisfação dessas necessidades, temos, genericamente, os serviços públicos, os serviços públicos sociais, se prestados, direta ou indiretamente, pelo Estado, sob o regime de Direito Público e de Direito Social.

Os beneficiários são os seus destinatários, figura fundamental nas instituições.

13.8. Pode concluir-se que a locução assistência social encerra um sentido compreensivo, abrangente de todas as modalidades assinaladas.

Não se confina este significado amplo com o sentido específico de assistência social, como parte da seguridade social, nos termos dos arts. 149, parágrafo único, e 194 da CF, como segmento diverso da previdência social.

É ela, inquestionavelmente, o gênero.

14. Para ser beneficiária da imunidade impositiva, a instituição de assistência social tem de revestir o caráter de entidade sem fins lucrativos, atendidos os requisitos da lei: $\mathrm{CF}$, art. $150, \mathrm{~V} \mathrm{I}, \mathrm{c}$.

15. A primeira observação que se pode fazer, é a comparação entre o teor do $\S 4^{\circ}$ do art. 150 da CF, com o do $\S 3^{\circ}$.

$O \& 3^{\circ}$, que se relaciona com a imunidade recíproca do inciso $\mathrm{VI}$, a, exige que não se trate de patrimônio, renda e serviços referentes a atividades econômicas regidas pelas normas aplicáveis a empreendimentos privados; ou em que haja contraprestação ou pagamento de preços ou tarifas.

Diversamente, no que toca ao $4^{\circ}$ do mesmo art. 150 e que tem pertinência com a imunidade das instituições de assistência social, exige-se, apenas, que o patrimônio, a renda e os serviços da instituição sejam os "relacionados com as finalidades essenciais" da entidade.

É, indubitavelmente, dado básico no exercício da interpretação sistemática da matéria em tela.

15.1. É interessante, outrossim, anotar que a CF de 1946 (art. 31, V, b) exigia, tão-somente, que as rendas das instituições em tela fossem aplicadas integralmente no País para os respectivos fins.

A Lei $\mathrm{n}^{\mathfrak{Q}} 3.193$, de 04.07.57, editada no regime de 46 , limitava-se a repetir o requisito constitucional (art. $1^{\mathbf{9}}$ ).

A Emenda Constitucional $\mathrm{n}^{2} 18$, de $1^{2} .12 .65$, que revolucionou o sistema tributário nacional, e a Carta de 67/69 deixavam à legislação infraconstitucional a fixação dos requisitos a serem observados pelas entidades, para serem imunes (arts. 20, III, $c$; e 19, III, $c$, respectivamente).

Já o Código Tributário Nacional, que é a Lei $\mathrm{n}^{\circ} 5.172$, de 25.10 .66 , com ulterior força de lei complementar, estabeleceu, em seu art. 14, os seguintes requisitos:

"I - não distribuírem qualquer parcela de seu patrimônio ou de suas rendas, a título de lucro ou participação no seu resultado; II aplicarem integralmente, no País, os seus recursos na manutenção dos seus objetivos institucionais; III - manterem escrituração de suas receitas e despesas em livros revestidos de formalidades capazes de assegurar sua exatidão."

A Constituição de 1988 prestigiou o requisito de ser a instituição sem fins lucrativos e de atender aos requisitos da lei: art. $150, \S 49$.

15.2. Adotando-se classificação norte-americana, podemos afirmar que existem dois tipos de entidades não-lucrativas: as instituições non profit e aquelas que são not for profit. 
As primeiras são as que nada cobram pelo que fornecem, sejam serviços ou mercadorias.

Nas outras, os serviços são remunerados, seja a preço de mercado, seja por valores menores.

A característica comum é a gratuidade das funções de seus administradores estatutários e a não-distribuição de lucros ou participações.

Assim, uma entidade not for profit não visa a resultados econômico-financeiros positivos em benefício de membros ou gestores, embora cobre pelo que oferecem, eis que o objetivo é reaplicar a receita na manutenção de seus serviços, na preservação de aumento de seu patrimônio e recursos.

15.3. Podemos afirmar que, em nosso regime jurídico, o conceito de entidade sem fins lucrativos abrange ambas as categorias.

O próprio CTN, no art. 14, I, como não poderia deixar de ser, admite um resultado econômico financeiro positivo: o que está proibido é a participação neste resultado e a distribuição de qualquer parcela de seu patrimônio ou de suas rendas a título de lucro.

A Lei das Sociedades por Ações (Lei $n^{\mathrm{Q}}$ 6.404, de 15.12.76), em seus arts. 189 e seguintes, trata do resultado do exercício; das participações, dos dividendos.

O lucro líquido é o resultado do exercício, depois de deduzidos os prejuízos acumulados, as provisões e participações.

Tem ele destinações específicas: a constituição de reservas e a distribuição de dividendos.

A função ou comprometimento finalístico é que faz diferir o lucro empresarial, do resultado econômico positivo das entidades não-empresariais, eis que o segundo não pode servir para participações ou distribuição de dividendos, mas, tão-somente, para aumento do patrimônio.

15.4. Fica claro, portanto, que ser 'sem fins lucrativos' significa não distribuir qualquer parcela de seu patrimônio ou de suas rendas, a título de lucro ou participação no seu resultado.

Verifica-se, pois, que o requisito contido no inciso I do art. 14 do CTN é o que traduz a exigência prescrita pelo art. 150, IV, c, da CF, o que é compreensível, eis que a Carta de $67 / 69$, em seu art. $2^{2}$, IV, $c$, remetia todos os pressupostos para a infraconstitucionalidade.

15.5. O elenco dos requisitos do art. 14 é numerus clausus, e, assim, coincidindo o primeiro deles com o que tem assento constitucional, restam, apenas, os dois outros, para a configuração do suporte fático do direito à imunidade, que, na lição de PONTES (Comentários à Const. de 1967 cit., II: 397), “é direito do status negativus, como o são os direitos de liberdade”. E completa: "a pretensão é à imunidade, pretensão, portanto, à liberdade, à incolumidade, em frente à imposição fiscal". Trata-se de direito absoluto concernente a impostos.

15.6. Outras exigências não são pertinentes, nem por leis ordinárias federais, nem por leis locais.

A lei que estabelece os requisitos é somente a lei complementar federal, e apenas prevalecem, no momento, os requisitos exigidos pelo art. 14 do CTN.

SACHA CALMON comenta (Comentários à Constituição de 1988 cit., p. 353): "Estas pessoas políticas não podem instituir outros requisitos além dos previstos na lei complementar da Constituição, que a todos obriga. Tampouco, depende o gozo da imunidade de requerimento ou petição. $O$ imune, enquadrando-se na previsão constitucional, observados os requisitos, tem, desde logo, direito. Não pagará imposto, desnecessária autorização, licença ou alvará do ente político cujo exercício da competência está vedado (a imunidade se abre para dois lados: à pessoa jurídica de direito público, titular da competência impositiva, proíbe o exercício da tributação; ao imune, assegura-lhe o direito de não ser tributado). Aceitável que o imune comunique ao ente tributante a sua condição e requeira o respectivo título. $O$ ato é facultativo."

15.7. A gratuidade dos serviços não é necessária, porquanto, do contrário, não haveria necessidade de vedar a instituição de impostos sobre aqueles, eis que a base de cálculo seria sempre 0 (zero).

15.8. HUGO DE BRITO MACHADO (Curso de Direito Tributário, $12^{\mathrm{a}} \mathrm{ed}$., 
197/198) tem o posicionamento interessante sobre o assunto: " $A$ imunidade das instituições de educação e de assistência social, todavia, é condicionada. Só existe para aquelas instituiçōes sem fins lucrativos, conceito que também tem sido muito mal compreendido. A lei não pode acrescentar requisitos a serem atendidos. Basta que não tenham fins lucrativos. É razoável, todavia, entender se que o não ter finalidade lucrativa pode traduzir-se no atendimento dos requisitos do art. 14 do Código Tributário Nacional, a saber. (a) não distribuirem qualquer parcela de seu patrimônio ou de suas rendas a título de lucro ou participação no seu resultado; (b) aplicarem integralmente no País os seus recursos na manutenção dos seus objetivos institucionais; (c) manterem escrituração de suas receitas $e$ despesas em livros revestidos de formalidades capazes de assegurar sua exatidão. Não ter fins lucrativos não significa, de modo nenhum, ter receitas limitadas aos custos operacionais. Elas na verdade podem e devem ter sobras financeiras, até para que possam progredir, modernizando e ampliando suas instalações. $O$ que não podem é distribuir lucros. São obrigadas a aplicar todas as suas disponibilidades na manutençāo dos seus objetivos institucionais. O meio para comprovar o cumprimento dessas exigências legais é a escrituração contábil. Daí a exigência do inciso III do art. 14 do CTN, de cunho meramente instrumental."

15.9. IVES GANDRA MARTINS (Comentários à Constituição do Brasil, 1990, $6^{\circ}$ vol., tomo I, p. 184,185 ) cita acórdão proferido pelo Tribunal de Justiça do Estado do Rio de Janeiro, em 26.12.72, no Agravo de Petição no 25.508 (Diário Oficial, seção III, de 09.08.73, p. 348), cuja ementa é a seguinte: "A lei citada não exige que a instituição seja desinteressada ou somente preste serviços gratuitos. Exige, simplesmente, que ela não distribua qualquer parcela de seu patrimônio ou de suas rendas, a título de lucros ou participações no seu resultado. Assim, os seus serviços prestados com remuneração sob qualquer forma, não a fazem perder o direito à imunidade fiscal, ainda que lhes proporcionem lucros e a tornem patrimonialmente próspera. A referida lei também não exige o requisito de não ser remunerada a diretoria da instituição e, dado o seu caráter de lei complementar á Constituição Federal, regulando, neste ponto, a imunidade nesta concedida, não pode sofrer modificações por lei estadual que o exija."

Reproduz, ainda, a lição de ALIOMAR BALEEIRO (p. 185): “Ainda nesses casos, insistimos em que a interpretação deverá repousar no estudo do alcance econômico do imposto em questão, nas circunstâncias do caso, e não no puro sentido literal das cláusulas constitucionais. A Constituição quer imunes instituições desinteressadas $e$ nascidas de espírito de cooperação com os poderes públicos, em suas atividades específicas. Ilude-a o intérprete que procura dissociar o fato econômico e o negócio jurídico, para sustentar que o dispositivo não se refere a este, de sorte que se justificaria imposto de transmissão 'inter vivos' sobre o ato da compra de imóveis por um partido ou Santa Casa de Misericórdia. Economicamente, é o imóvel que se encarece pelo efeito do tributo e a instituição que desfalca patrimônio votado integralmente a fim de interesse público no País" ("Direito Tributário Brasileiro'; Forense, 1981, p. 109/110).

15.10. SACHA CALMON (Coms. cit., p. 359 e s.) sustenta: 'Tampouco a 'gratuidade' da prestação se nos afigura fundamental enquanto nota do compósito instituição, como reconhece o Prof. LUIZ RICARDO GOMES ARANHA. O próprio Código Tributário $\mathrm{Na}$ cional prevê o lucro, tanto que veda sua distribuição ou sua remessa para fora do país. $O$ 'animus lucrandi' é explicitamente admitido na lei complementar tributária 'mater'. No campo das instituiçōes de educação, especificamente, é absolutamente natural que cobrem pelos serviços que prestam. $O$ que $o$ Código Tributário Nacional veda é tão-somente a apropriação particular do lucro. Este há de ser reinvestido no 'munus' educacional: melhor remuneração para professores, melhores condições ambientais, laboratórios, bibliotecas, centros de pesquisa, cursos de aperfeiçoamento para docentes, incrementos metodológicos etc. A disposição do Código 
Tributário Nacional é salutar. Quanto mais se faça pela educação, melhor. Essa 'gratuidade' pela qual tantos lutam é maléfica e contraproducente. Se as instituições particulares atuassem gratuitamente, a fundo perdido, logo se estiolariam em quantidade e qualidade. A idéia de permitir o lucro e de obrigar sua reinversão no munus educacional ou assistencial enquanto condição para o privilégio da imunidade é o verdadeiro motor do 'instituto', tomando-o útil e eficaz. A ampliação do campo de abrangência, da atuação das instituições, a seu turno, tem sido a grande, a inestimável contribuição da Suprema Corte à operacionalidade da imunidade das instituições. Com o decidir assim, o STF tem propiciado o surgimento de centenas de instituições a servir microcomunidades, em verdadeiro somatório de esforços visando a fim público inquestionável: a melhoria incessante dos niveis de educação, cultura e proteção assistencial do sofrido povo brasileiro. E assim, o que para LEOPOLDO BRAGA não passaria de uma outorga constitucional inédita e excepcional, sem correspondência noutras latitudes onde habitam sociedades mais cultas, passa a ser uma solução jurídica genuinamente brasileira para problemas que inexistem noutras latitudes, pelo menos com a intensidade e a dramaticidade com que se dão entre nós."

15.11. Aspecto cognato é o da remuneração de atividade-meio da instituição, desenvolvidas com o objetivo de obter receita a ser destinada a seu patrimônio, afetado aos fins da entidade.

A análise deste tópico exige um aprofundamento da cláusula, constante do teor do $\$ 4^{\circ}$ do art. 150 , segundo a qual a imunidade das instituições de assistência social compreende "somente o patrimônio, a renda e os serviços, relacionados com as finalidades essenciais das entidades nelas mencionadas."

15.11.1. Por isso, eventuais impostos incidentes sobre operações financeiras não podem atingir o ente da espécie.

No julgamento dos Embargos Infringentes em Apelação Cível $n^{2}$ 90.02.22504-7 (TRF-2 ${ }^{3}$ Região, Pleno, 08.08.91), votei no sentido de que, no tocante a fundações e instituições, "as aplicações financeiras a que procedem, são absolutamente inerentes ao atendimento de suas finalidades".

15.11.2. Observe-se, que nada há mais intrinsecamente econômico, do que a fundação e a instituição, porque, desde sua criação, e durante toda a sua existência, têm de ter patrimônio, conjunto de bens economicamente relevantes -, que haverá de, por aplicações e investimentos, produzir os rendimentos suficientes para que a entidade atenda a seus fins.

15.12. CELIO BORJA, em parecer sobre a matéria, assim se manifestou: " $A$ gratuidade da prestação de serviços, portanto, não é atributo ou nota essencial, nem das instituições públicas, nem das entidades privadas de beneficência, o que levou FERRARA a condenar como errôneas as opiniões, entre elas a de SAUZET, que assimilam a gratuidade dos serviços às pessoas jurídicas públicas, enquanto que as de direito privado teriam sempre finalidade lucrativa, entendendo-se por lucro o resultado ou rendimento mensurável em dinheiro que remunera o capital, permitindo a renovação dos bens que o constituem e a expansão da atividade; $e$, nas corporações, de fins lucrativos, a distribuição aos sócios. Pode afirmar se que a gratuidade específica da entidade beneficente é a doação, por seus instituidores, dos bens que lhe vão integrar o patrimônio e a dos serviços que seus dirigentes lhe prestam. Doadores, instituidores e diretores são, por isso, desinteressados, como se costuma dizer. O superávit produzido pela conta das receitas e despesas da pessoa jurídica, é um sinal da boa administração e é buscado, tanto pelas que têm fins lucrativos, como pelas que não têm. Nessas o lucro e o superávit sâo reinvestidos na atividade-fim. Cuidando da classificação das pessoas jurídicas à luz do Código Civil brasileiro, SILVIO RODRIGUES define as associaçōes, dentre as demais pessoas jurídicas, 'como agrupamento de individuos sem finalidade lucrativa, como os clubes esportivos, os centros culturais, as entidades pias etc'; contrastando, por isso, com as sociedades que para esse abalizado autor são agrupamentos individuais com escopo de lucro. Observando que 
essa especialização dos fins das pessoas jurídicas não está expressamente acolhida no Código Civil, CAIO MÁRIO DA SILVA PEREIRA conclui que todas elas, sociedades $e$ associações, assim as de fins econômicos, como as não lucrativas, pelo fato de terem patrimônio, devem mantê-lo e aumentá-lo, buscando os meios materiais que lhes permitam alcançar seus fins. Por isso, o que caracteriza a associação ou sociedade sem fins lucrativos é a proibição estatutária de oferecer vantagens a seus componentes, não lhes sendo vedado auferir receitas e fazer crescer seu patrimônio."

15.13. É de voto do Ministro SYDNEY SANCHES o seguinte trecho (RTJ, 131: 1306/77: "Descarte-se o requisito da gratuidade. O CTN não o prevê. Animus lucrandi podem e até devem ter as instituições. $O$ que não se admite é o animus distribuendi. A gratuidade, já doutrinariamente, já por inserção do art. 14 do CTN, há de ser entendida como ausência final de ânimo de lucrar. Pode, $e o$ CTN o pressupõe, haver lucro; desde que não seja o móvel da pessoa e que haja a total reversão dos resultados aos fins sociais que devem ser benemerentes. Benemerência que não é só a 'Pietà' e a filantropia, quer dizer atender a carentes, em condições excepcionais em relação ao mercado. Desta forma, não desnatura a instituição de educação ou assistência social ter serviços ou praticar atos que resultem em lucro ou resultados financeiros" (SACHA CALMON, 'in' Revista de Direito Tributário; vol. 35/129). O recorrente não é empresário. $O$ recorrente nāo explora comercialmente os cinemas de sua propriedade, ou, para usar a expressão utilizada pela lei complementar (Decreto-lei $n^{Q}$ 406), não presta serviço de diversões públicas em caráter empresarial, isto é, com o objetivo de auferir lucros para serem distribuídos a seus associados ou administradores. É neste sentido que deve ser interpretado o art. 14, I, do Código Tributário Nacional. A instituição de assistência social não está proibida de obter lucros ou rendimentos que podem ser $e$ são, normalmente, indispensáveis à realização de seus fins. $O$ que elas não podem é distribuir lucros. Impõe-se-lhes o dever de aplicar os rendimentos 'na manutenção dos seus objetivos institucionais'. O legislador complementar dos impostos sobre serviços parece que teve em vista, exatamente, preservar essas entidades, quando redigiu o art. $8^{\circ}$ do Decreto-lei $n^{2} 406 / 68$, cuja vigência foi manifestamente negada pelo $v$. Acórdão recorrido: ' $O$ imposto, de competência dos $\mathrm{Mu}$ nicípios, sobre serviços de qualquer natureza, tem como gerador a prestação por empresa ou profissional autônomo, com ou sem estabelecimento fixo, de serviços constante na lista anexa.' A expressão empresa, ninguém põe em dúvida, está utilizada em seu sentido técnico, isto é, como significando uma unidade econômica organizada, com finalidade lucrativa (cf. BERNARDO RIBEIRO DE MORAES, 'Doutrina e Prática do ISS'; p. 96).

E aduz: " $A$ Constituição e o Código Tributário Nacional, ao conferirem imunidade aos bens, serviços e rendas, das instituiçōes de educação e assistência social supõem, necessariamente, que elas as aufiram da prestação de serviços remunerados. Só a remuneração de serviços e os resultados de investimentos ou, mesmo, de aplicações financeiras, podem realizar o saudável objetivo de colocar essas entidades ao abrigo da necessidade de recorrer à caridade oficial ou particular, sempre volúvel e precária. Assim entendidos os preceitos constitucional e da lei complementar é evidente, $d$. v., que a habitualidade da execução de serviços retribuídos é, não apenas, irrelevante para o efeito de excluir a imunidade, como, também, recomendável ou louvável, para habilitar a instituição a cumprir seu relevante objetivo. $O$ que a Constituição e o Código Tributário não permitem é a distribuição das rendas a associados ou administradores".

15.14. Os serviços sociais autônomos clássicos, com criação por lei, mesmo com ligações com o setor privado, como os dos chamado Sistema 'S' - SESI, SESC, SENAI, SENAC e SEBRAE - gozam de imunidade impositiva, com fulcro na vedação do art. 150 , VI, $c$ da CF.

Citemos decisão a respeito:

"EMENTA: IMUNIDADE TRIBUTÁRIA. CF, ART. 150, VI, C. SERVIÇO SOCIAL DO COMÉRCIO SESC. IMPOSTO SOBRE SERVICOS. PRESTAÇÃO DE SERVIÇOS DE DI- 
VERSÃO PÚBLICA. A renda obtida pelo SESC na prestação de serviços de diversão pública, mediante a venda de ingressos de cinema ao público em geral, e aproveitada em suas finalidades assistenciais, estando abrangida na imunidade tributária prevista no art. 150, VI, c, da Carta República. Precedente da Corte: RE 116.188-4. Agravo regimental improvido." (STF, RTJ 131: 1.295)

16. Outra exigência indevida é o atributo da generalidade, de tratar-se de fundação ou instituição aberta, que permita o acesso de qualquer pessoa à situação de seu beneficiário ou destinatário.

16.1. O que é necessário é que haja impessoalidade, ou seja, que os destinatários não sejam pessoas determinadas, mas possam sêlos todos os que preencham os pressupostos para a aquisição da condição.

Essa é uma forma de generalidade, como ocorre com a lei: é geral para todos os que atendam aos requisitos para serem seus destinatários.

Impessoalidade é o oposto da particularidade, da individualidade: os destinatários são indeterminados, embora determináveis.

Em matéria de fundação, de instituição, a impessoalidade, quanto aos destinatários, é qualificação inafastável, porquanto seus beneficiários não podem ser prenominados.

16.2. A entidade fechada, como na previdência pública ou privada, acessível ao conjunto de servidores, de empregados, e respectivos dependentes, de um único ente federativo ou de uma empresa, é válida, pois que, continua a haver a impessoalidade.

SACHA CALMON desenvolve (op. cit., p. 359 e s.): " $O$ ideal é precisamente a proliferação de associações, fundações, pessoas civis, que se ocupem institucionalmente dos papéis assistencial, cultural e educacional, ainda que no âmbito de uma só empresa, como ocorre com a Fundação Rubem Berta, da Varig, cuja imunidade, antes contestada, foi reconhecida pelo STF, em 1971, em histórica decisão. Muitas outras empresas possuem organismos institucionalmente voltados para a educação e o 'munus' assistencial (lazer, colônias de férias, auxílios diversos, empréstimos de emergência, centros de treinamento, bolsas de estudo, complementação de aposentadoria, cultura, cooperativas de consumo etc.) merecem a imunidade. (...) A palavra 'instituição' não tem a ver com tipos específico de entes jurídicos, à luz de considerações estritamente formais. É preciso saber distinguir quando a distinção é fundamental e não distinguir quando tal se apresente desnecessário. 'instituição' é palavra destituída de conceito jurídico-fiscal. Inútil procurá-lo a pui ou alhures, no direito de outros povos. $E$ um 'functor' operacional. O que a caracteriza é exatamente a função e os fins que exercem e buscam, secundária a forma jurídica de sua organização, que tanto pode ser fundação, associação etc. $O$ destaque deve ser para a função, os fins. Irreprochável o acórdão do STF que deu desfecho ao caso do serviço social da indústria do papel, papelão e cortiça do Estado de São Paulo, lavrado pelos Mins. MOREIRA ALVES, DJACI FALCÃO, LEITÃO DE ABREU e CORDEIRO GUERRA: 'Imunidade tributária, art. 19, III, c, da Emenda Constitucional. É instituição de assistência social, entidade mantida por empresas para prestar, gratuitamente, serviços de assistência a diretores, empregados e dependentes destes, uma vez que, além de preencherem os requisitos do art. 14 do Código Tributário Nacional, auxiliam o Estado na prestação de assistência social aos que necessitam dela, embora em área circunscrita' (RE $n^{Q}$ 89.012, de 1978, Rel. MOREIRA ALVES, Tribuna da Justiça, jurisprudência, p. 168, de 10.10.79). O critério da generalidade da prestação educacional ou assistencial, destarte, não encontra eco na Suprema Corte, como note do compósito instituição. A Corte atua pragmaticamente. Vê os fins, as funções do ente assistencial ou educacional, ainda que restrito o seu raio de atuação. E, convenhamos, com grande senso de realidade $e$ justiça. (...) A jurisprudência da Suprema Corte ao propósito é alentadora. Vale a pena lembrar o acórdão que reconheceu imunidade à Fundação Rubem Berta da Varig, embora cobrasse de seus beneficiários e só a eles atendessem (RE no 70.834, RTJ, 65: 145)."

16.3. Na Uniformização de Jurisprudência de que decorreu a Súmula $\mathrm{n}^{\mathrm{e}} 05$ do TRF-2 ${ }^{\mathrm{a}}$ 
Região, votei (julgamento de 02.05.91): “Irrelevância do caráter 'fechado' da entidade, que tem sentido genérico, na medida em que qualquer empregado da empresa patrocinadora ou do grupo de empresas pode ser beneficiário."

17. Para a fundação, a instituição, o patrimônio é básico.

A própria etimologia do termo fundação mostra que ela é, em verdade, um fundo personalizado, conforme antes salientado.

Por seu turno, uma instituição, como a PARANAPREVIDÊNCIA, cujo patrimônio é constituído de Fundos Assistenciais, previdenciário e médico-hospitalar, está todo ele afetado aos fins públicos a que persegue.

Neste sentido, em termos fundacionais e institucionais, basta, em verdade, vedar a instituição de impostos sobre o patrimônio, que se está protegendo, na sua integralidade, a própria entidade. E, por outro lado, todos os impostos que atinjam a esta, repercutem sobre seu patrimônio.

A distinção que, muitas vezes, se faz, nos estatutos, entre patrimônio e receita, não infirma o exposto, porquanto tão-somente caracteriza as fontes de acréscimo patrimonial; e, em certos casos, discriminam ingressos que são afetados, de modo imediato, aos dispêndios com os fins da entidade, chamados, por isso mesmo, de fins institucionais, sendo o resíduo incorporado definitivamente ao fundo patrimonial.

17.1. Fala-se de patrimônio, rendas e serviços.

17.2. Todo patrimônio é, juridicamente, uma universalidade (art. 57 do Código Civil).

Existe o patrimônio pessoal, o patrimônio individual que PONTES DE MIRANDA compara à sombra de cada pessoa - constituído dos direitos sobre bens econômicos, bens com valor pecuniariamente mensurável.

Conjugando-se as regras constitucionais sobre o Sistema Tributário Nacional e o respectivo Código, no Capítulo III do Título III do Livro Primeiro, conclui-se que são impostos sobre o patrimônio: (a) impostos sobre transmissão de bens e direitos; (b) imposto sobre a propriedade territorial e predial urbana; (c) imposto sobre a propriedade territorial rural; (d) impostos sobre propriedade de veículos automotivos; (e) imposto sobre grandes fortunas.

17.3. Não se restrinja a noção de patrimônio à de propriedade no sentido de domínio, de direito real máximo (arts. 485, in fine, e 524 do Código Civil).

É que, ao contrário, quando a $\mathrm{CF}$ assegura a garantia da propriedade, nos arts. $5^{2}$, XXII e LIV; 150, IV; e 170, II; o faz em sentido amplo, abrangendo os direitos de propriedade, isto é, todos os direitos de conteúdo econômico, cujo objeto tenha valor pecuniário (valor de uso e valor de troca).

17.4. Neste significado abrangente é que deve ser tomado o termo patrimônio, como conjunto de direitos de valor econômico, incluindo a propriedade e os demais direitos reais; a posse; os direitos obrigacionais; os direitos a prestações pecuniárias com base no direito sucessório, no direito administrativo etc.

Destarte, em seu sentido compreensivo, direitos de propriedade e direitos patrimoniais são expressões equivalentes; e, como conjuntos, como universalidades, são propriedade lato sensu e patrimônio termos equivalentes.

Lembremos que o patrimônio é constituído de direitos: assim, por exemplo, não é o imóvel que integra o patrimônio de $A$, mas seu direito de propriedade sobre o mesmo.

17.5. Acrescentemos que, ao lado do patrimônio econômico, existem outros, cujos integrantes são direitos cujo valor é de diferente natureza, como os vários patrimônios sociais; dentre eles o cultural, em que o valor é o histórico, o artístico, o arqueológico, o paleontológico, o ecológico, o científico, o tecnológico, o turístico, o estético (CF, arts. 216 e incisos; Lei $n^{2} 7.347$, de 24.07 .85 , art. $1^{2}$, I e III).

17.6. Ademais, nesta amplitude plena, não apenas direitos integram o patrimônio, mas igualmente interesses, os chamados interesses legítimos, protegidos pelo Direito, a abarcar, não somente, portanto, os de natureza individual, como também os de índole transindivi- 
dual, difusa e coletiva (Lei $\mathrm{n}^{2} 7.347 / 85$, art.

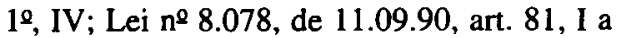
III).

A CF de 1946, no art. 31, V, b, falava de bens, termo substituído por patrimônio, na Carta de 67/69 (respectivamente, arts. 20, III, a; e 19, III, a).

Os bens são objeto de direitos e interesses legítimos, e eles é que contém o valor (econômico ou de outra natureza) que dá unidade, que confere identidade a um patrimônio.

Sabemos que nem todo bem é coisa, havendo os de várias naturezas e conteúdo.

18. O conceito de rendas abrange a renda, que é o produto do capital, do trabalho ou da combinação de ambos: CTN, art. 43 , I; e os proventos de qualquer natureza, eis que são eles "os acréscimos patrimoniais" não compreendidos na noção anterior (art. 43, II), o que, de qualquer modo, está ligado ao conteúdo do patrimônio, também imune, como se sabe.

Sustentava, com propriedade, ALIOMAR BALEEIRO (Limitações Constitucionais ao Poder de Tributar, Rio, Forense, $2^{2}$ ed., 1960, p. 123/124), no regime da CF de 1946, que rendas são quaisquer ingressos, dentro da cláusula genérica que aquela Carta empregava com relação à imunidade recíproca: "quaisquer outras rendas que possam advir de suas atribuições e da utilização de seus bens e serviços" (art. 30, III).

Nesta linha, nenhum imposto que acarrete o desfalque da renda, da receita, do ingresso, sejam preços, juros, ágios, lucros, dividendos, prêmios, rendimentos em geral, inclusive de aplicações e investimentos, poderá ser, no particular, instituído, o que envolve o imposto sobre renda e proventos de qualquer natureza, como aquele sobre operações de crédito, câmbio e seguro, ou relativas a títulos ou valores mobiliários (CF, art. 153, V).

19. A cláusula, que figura no $\S 4^{\circ}$ do art. $150 \mathrm{da} C F$, relacionados com as finalidades essenciais da entidade refere-se aos serviços.

19.1. Quanto a serviços relacionados com suas finalidades essenciais, cabe lembrar que todo o patrimônio da instituição está compro- metido com as finalidades essenciais da entidade.

A administração da entidade consiste na gestão deste patrimônio, com um só objetivo: a consecução das finalidades institucionais.

A utilização de qualquer recurso, em finalidade que não seja institucional, caracteriza ilicitude administrativa, como forma de desvio de poder.

19.2. O corte no conteúdo do poder governamental de tributar, quanto a templos de qualquer culto, partidos políticos e suas fundações, entidades sindicais de trabalhadores, e instituições de educação e de assistência social, além da condicionante de natureza subjetiva, referente à própria entidade, qual seja a de não serem as mesmas sem fins lucrativos, exige outra, a ligada aos seus serviços: que sejam eles "relacionados com as finalidades essenciais das entidades" referidas.

19.3. Relacionado traduz várias formas de aproximação entre dois objetos, podendo corresponder à relação de causa e efeito, de analogia, de correspondência, de sucessão, de coexistência, de conexão etc.

A diç̧ão da $\mathrm{CF}$, no $\S 4^{\circ}$ do art. 150 , não repete o $\$ 2^{\circ}$ do art. 14 do CTN, que fala de serviços diretamente relacionados, o que é altamente significativo.

19.4. E o termo serviços está tomado, no texto imunizante, em sentido largo, mesmo porque já era usado na Carta de 1946 (art. 31, $\mathrm{V}, \mathrm{b}$ ), que não previa o imposto sobre serviços, mas o de indústrias e profissões, de licença e sobre diversões públicas (art. 26, I a IV).

19.5. O conceito de serviços, como fato gerador, já é, tributariamente, amplo, pois que eles são prestados pela atividade ou pela colocação de coisas à disposição de outros, como na locação de bens, no estacionamento de veículos.

Há, de qualquer modo, hipóteses de conjunto interseção do imposto sobre serviços com o ICMS, na parte de operações com circulação de mercadorias, como no fornecimento de alimentação, incluído na diária de hospedagem (n 99 da Lista de Serviços anexa ao Decreto-lei $\mathrm{n}^{\mathrm{2}} 406$, de 31.12.68). 
19.6. ALIOMAR BALEEIRO (Limitações Constitucionais ao Poder de Tributar, Rio, Forense, $2^{\mathrm{a}}$ ed., 124 e 184), ao estender os elementos básicos da noção do serviço público aos serviços das instituições de educação e de assistência social, dá ênfase ao aspecto do serviço enquanto organização de pessoal e de material, para desempenho de funções e atribuições de sua competência, " enfim de todos os meios de operação", sob as várias modalidades para realização dos fins que, expressa ou implicitamente, são cometidos à entidade, independentemente do objeto da atividade.

Essa ênfase, posta no aspecto organizacional, estrutural, subjetivo, portanto, atende à índole da própria imunidade, também subjetiva.

Observe-se que a fundação, a instituição, como pessoa jurídica objetiva, é patrimônio, mas também é estrutura, tanto que o CPC (arts. 1.199 e s.) prestigia sua organização; e o Código Civil, a sua administração (art. 24).

Nesta linha, também os impostos sobre a produção e a circulação (imposto sobre produtos industrializados - $\mathrm{CF}$, art. 153, IV; sobre operações de crédito, câmbio e seguro, ou relativas a títulos ou valores mobiliários - art. $153, \mathrm{~V}$; sobre operações relativas à circulação de mercadorias - art. 155 , II) estão afastados.

19.7. Ao excluir os serviços das entidades em pauta a CF tornou-as imunes do imposto estadual sobre prestações de serviços de transporte e interestadual e intermunicipal e comunicação (art. 155, II), subsumido no ICMS; e do imposto municipal sobre serviços de qualquer natureza, definidos em lei complementar (art. 156, III).

20. Não nos parece que, ao tratar da imunidade em pauta, a CF, aludindo a "instituir impostos sobre patrimônio, rendas e serviços”, tivesse querido caracterizar, tão-só, o fato gerador, a situação jurídica, o assento ou a base de cálculo do imposto, mas sim que busca proteger o patrimônio e rendas contra desfalques em decorrência da impo- sição; e os serviços, além disso, também sua oneração para a instituição ou para seus destinatários.

20.1. Neste passo, é imprescindível acentuar-se a ratio da imunidade impositiva, in casu.

Segundo o entendimento dominante, o fundamento básico que justifica a outorga de imunidade tributária às entidades de educação e assistência social está em que as mesmas prestam serviços de interesse público, sem fins lucrativos, destinando, assim, a integralidade de seu patrimônio e rendas a essas atividades, pelo que já seriam, de fato, contribuintes de impostos in natura e in labore, na proporção de cem por cento.

20.2. Daí não caberem as divergências quanto à prevalência da imunidade, em se tratando de impostos indiretos, seja quando, com relação a eles, a instituição é contribuinte de direito ou de fato.

No particular, a melhor colocação da questão é a de que, em se tratando de impostos sobre patrimônio, rendas e serviços, as entidades educacionais estão imunes, quer sejam contribuintes de jure ou de facto.

\section{III — CONCLUSÃO}

Em face do exposto, verifica-se que, tal como consta do art. 100 da Lei PR $n^{2}$ 12.398/98, a PARANAPREVIDÊNCIA é destinatária da imunidade impositiva assegurada pelo art. 150, VI, da CF: (a) quer, nos termos de sua alínea a, e do $\S 2^{2}$, por ser serviço estadual, sob a forma de fundação-instituição, criada pelo Estado do Paraná, que é seu mantenedor; (b) quer, conforme o disposto na letra c, e $\S 4$, , por caracterizar-se como instituição de assistência social.

Do Rio de Janeiro para Curitiba, 21 de janeiro de 2000

SERGIO DE ANDRÉA FERREIRA

Advogado e Professor Titular no Rio de Janeiro

OAB-RJ $n^{2} 79.890$ (OAB-GB $\left.n^{2} 11.417\right)$ 